\title{
Development of morphological types and distribution patterns of amacrine cells immunoreactive to tyrosine hydroxylase in the cat retina
}

\author{
HOU-HUA WANG, ${ }^{1}$ NICOLAS CUENCA, ${ }^{2}$ aND HELGA KOLB ${ }^{3}$ \\ 'Shanghai Institute of Physiology, Academia Sinica, Shanghai, China \\ ${ }^{2}$ Department of Histology, University of Alicante, Alicante, Spain \\ ${ }^{3}$ Departments of Physiology and Ophthalmology, University of Utah School of Medicine, Salt Lake City \\ (ReCeived September 24, 1989; ACCEPTEd November 28, 1989)
}

\begin{abstract}
Using an antibody against tyrosine hydroxylase on newborn to 30-day kitten retinas, we have been able to follow the development of the dopaminergic amacrine cells of the cat retina by light-microscopical investigations of retinal wholemounts. The Type 1 or large Toh + amacrine cells described by others (Oyster et al., 1985; Törk \& Stone, 1979) and named A18 from a Golgi study (Kolb et al., 1981), is at birth (P1) an immature neuron with a small cell body and two or three simple thick radiating dendrites stratifying in stratum 1 with many of the dendrites ending in enlarged growth cones. With increasing postnatal age, the cell body size increases from $12.5 \mu \mathrm{m}$ diameter to reach $15.5 \mu \mathrm{m}$ diameter at P30. The dendritic fields also increase in size and complexity. At P1, cells of the central area exhibit dendritic appendages which then develop progressively until at P13 (after eye opening) they are part of rudimentary rings and by P30 the dendritic plexus of Toh+ dendrites and rings in stratum 1, typical of the adult cells, are complete. Toh+ stained processes with growth cones that run deep in stratum 5 of the inner plexiform layer and processes passing to the outer plexiform layer first become apparent at $\mathrm{P} 1$ in cells of central inferior retina but not till after P13 are these processes clearly expressed. At P1, the total number of Toh+ Type 1 cells is approximately 4000 and this number remains unchanged to the adult retina. However, the retina increases in size over the P1-P30 stage and thus the mean density of Type 1 Toh + cells decreases from $30 / \mathrm{mm}^{2}$ at $\mathrm{Pl}$ to $18 / \mathrm{mm}^{2}$ at P30. The maximum density of Type 1 Toh + cells occurs in central retina 2-4 mm superior temporal to the area centralis, corresponding to the maximum rod photoreceptor concentration.

A second type of small Toh + amacrine cell can be visualized at P1. This Type 2 cell is characterized by a much smaller cell body than Type 1 cells $(9 \mu \mathrm{m}$ diameter $)$, and with faintly stained dendrites located in stratum 3 of the inner plexiform layer. During later postnatal days, Type 2 cells gradually become unstainable and only few are still seen in far peripheral retina by P23. Type 2 Toh + cells form a total population of 40,000 cells at $\mathrm{P} 1$ with their highest density occurring in peripheral retina. By P13, they cannot be seen in central retina and are reduced to a total population of cells staining for the antibody of 7400 cells in far peripheral retina. Their density decreases from $233 / \mathrm{mm}^{2}$ at P1 to $0 / \mathrm{mm}^{2}$ at P30. The transiently staining population of Type 2 Toh + immunoreactive cells probably correspond to the small THI-CA-cell seen in rat retina (Nguyen-Legros et al., 1983), and the second type of dopaminergic amacrine cell seen in macaque retina (Mariani \& Hokoc, 1988).
\end{abstract}

Keywords: Immunohistochemistry, Retina, Toh + amacrine cells, Development

\section{Introduction}

Staining adult cat retina with tyrosine hydroxylase (Toh) immunohistochemistry demonstrates a type of amacrine cell with a large cell body, with dendrites forming a plexus of interdigitating dendrites in stratum 1 (Hokoc \& Mariani, 1988; Kolb et al., 1990; Oyster et al., 1985; Törk \& Stone, 1979) and with some long "axon-like" processes running in stratum 5 of the inner

Reprint requests and correspondence to: Helga Kolb, Physiology Department, University of Utah School of Medicine, 410 Chipeta Way, Research Park, Salt Lake City, UT 84108, USA. plexiform layer (IPL) (Kolb et al., 1990). Some of these large Type 1 dopaminergic amacrine cells in cat retina are displaced to the ganglion cell layer and some give rise to "interplexiformlike" processes ramifying in the outer plexiform layer (OPL) (Kolb et al., 1990; Oyster et al., 1985). In other species of mammalian retina, a second type of catecholamine cell also stains with Toh+ immunohistochemistry (Mariani \& Hokoc, 1988; Nguyen-Legros, 1988; Nguyen-Legros et al., 1983). This Type 2 catecholaminergic cell is characterized by a small cell body, distribution preferentially in peripheral retina and a dendritic stratification pattern quite different from the large Type 1 cells, 
in being confined to the middle of the IPL in stratum 3. Type 2 amacrine cells have not been described as staining with Toh antibodies in the cat retina.

It is now known that ganglion cells are the first generated retinal neurons with amacrine cells following a few days later. The earliest synapses in the IPL in cat are found at embryonic day 36 in the central retina (Stone et al., 1984). However, peripheral retina is slower to be differentiated and synapses in the IPL are barely recognizable at the day of birth and certainly synaptogenesis continues until well into the P20s (Johns et al., 1979; Morrison, 1982). So although the amacrine cell types are already generated and beginning to form connections in central retina by birth, much synaptogenesis and developing of connectivity proceeds after birth, particularly in peripheral retina. In fact, final bipolar cell connections with amacrine cells and ganglion cells occur simultaneously with eye opening in cat and rabbit (McArdle et al., 1977; Morrison, 1982) and some days postnatally in monkey retina (Nishimura \& Rakic, 1985). The commitment of neurons to be transmitter specific is almost certainly made before birth (Lam et al., 1981), but the maturation of these neurons into becoming involved in their eventual synaptic circuits happens some time after birth. In the case of GABA and glycine, this happens about the time of eye opening in the rabbit retina (Kong et al., 1980; Lam et al., 1980) while it is delayed until postnatal day P25 for the maturation of the dopaminergic amacrine cells (Lam et al., 1981).

We now know the details of the synaptic connections of the Type 1 dopaminergic amacrine cell in the cat, and it is clear that these amacrine cells have a primary role in neurocircuitry of the GABA and glycinergic amacrine cells of the rod system (Hokoc \& Mariani, 1988; Kolb et al., 1990; Mariani et al., 1984; Voigt \& Wässle, 1987). It seems of considerable interest to ascertain how the dendritic morphology develops including the formation of the rings of the stratum 1 plexus and the "axon-like" processes of stratum 5 during the course of the first $30 \mathrm{~d}$ postnatally. It would also be of interest to determine parallels between distribution of the maturing dopaminergic amacrine cells of the kitten and the distribution of these other GABA- and glycinecontaining rod pathway neurons which we know to have matured earlier.

In this paper, we describe the maturation of the complete dendritic morphology of Type 1 Toh + amacrine cells over the course of $30 \mathrm{~d}$ from postnatal day $1(\mathrm{Pl})$ as seen in wholemount and sectioned retinas. We note that the formation of rings of the mature dendritic plexus in stratum 1 begins after eye opening (P10) and that it is not completed until P30. Simultaneously the formation of the stratum 5 "axon-like" processes and "interplexiform-like" processes occurs. We have also observed a transient staining with Toh+ antibodies of the Type 2 catecholamine cells described by others (Mariani \& Hokoc, 1988; Nguyen-Legros, 1988; Nguyen-Legros et al., 1983).

\section{Methods}

\section{Antisera}

Primary antibody made against rabbit tyrosine hydroxylase (Toh) was purchased from Eugene Tech, USA. Biotinylated anti-rabbit IgG (made in goat) and the avidin-biotin peroxidase (ABC) kits were obtained from Vector Labs, USA, or from the Shanghai Institute of Biological Products, China. In this study, the concentration of antiserum was $1: 500$ to $1: 1000$ for the pri- mary antibody and 1:100 for the subsequent antisera. $0.3 \%$ Triton $\mathrm{X}-100$ was added to the antisera for the light-microscopical immunohistochemistry.

\section{Tissue preparation}

Postnatal kittens between the ages of P1 (day of birth) to P30 were deeply anesthetized with Nembutal $(40 \mathrm{mg} / \mathrm{kg})$ and perfused with warm saline followed by cold fixative consisting of $4 \%$ paraformaldehyde and $0.2 \%$ glutaraldehyde in $0.1 \mathrm{M}$ phosphate buffer (PBS) ( $\mathrm{pH} \mathrm{7.4)} \mathrm{and} \mathrm{switched} \mathrm{to} 4 \%$ paraformaldehyde alone in PBS. Both eyes were enucleated and hemisected. The retinas were isolated from the choroid and bleached with $0.3 \% \mathrm{KMNO}_{4}$ in $0.3 \% \mathrm{H}_{2} \mathrm{SO}_{4}$ and $2.5 \% \mathrm{NaHSO}_{3}$ to eliminate the pigment granules of the pigment epithelium. Fixation continued in fresh $4 \%$ paraformaldehyde in PBS for $1 \mathrm{~h}$ followed by $4 \%$ paraformaldehyde in sodium biborate buffer at higher $\mathrm{pH}(\mathrm{pH} \mathrm{10.1)}$ for a further $2 \mathrm{~h}$. After treatment with $0.5 \%$ $\mathrm{NaHB}_{4}$, the retinas were placed in $25 \%$ sucrose in PBS overnight at $4^{\circ} \mathrm{C}$. The next day, the retinas were taken through a freeze-thaw procedure, washed in PBS, and pre-incubated in $2 \%$ normal goat serum in PBS overnight at $4^{\circ} \mathrm{C}$. Incubation in the primary Toh antibody was done for 3-4 $\mathrm{d}$, followed by incubation for 1-2 $d$ in the goat anti-rabbit $\operatorname{IgG}$, and in the $A B C$ complex for 1-2 $d$ using a shaker and refrigeration. Finally, the retinas were treated with diamino-benzidine (DAB) and $\mathrm{H}_{2} \mathrm{O}_{2}$ by standard techniques and mounted in gelatin on slides for viewing as wholemounts by light microscopy. Shrinkage of the retina was estimated to be $5 \%$. Some retinas were dehydrated through graded alcohols and embedded in Epon between plastic coverslips so that they could be cut in vertical $20-\mu \mathrm{m}$-thick sections on a rotary microtome.

\section{Analysis of cell populations and distributions}

Well-stained wholemount retinas were examined and all of the stained Type 1 cells marked on a map of the retina drawn with the camera lucida using a $6.3 \mathrm{X}$ objective. Examples of wellstained cells at the different developmental times were drawn and photographed. Type 2 cells were counted, using an eyepiece graticule, as they occurred in the retina on the horizontal and vertical axes.

\section{Results}

\section{Morphology of developing Toh+ amacrine cells}

\section{Toh + amacrine cells in newborn kitten retina $(P I)$}

Toh+ staining of wholemount newborn kitten retina reveals the presence of two types of stained amacrine cells (Fig. 1). A large, irregular, darkly stained cell type is prominent, but many small faintly stained cell bodies are also present (Fig. 1, open arrows). The large, darkly stained Toh + cell is the Type 1 dopaminergic amacrine cell. In central retina (Figs. 1, 2b, and 3b), these cells have 11-12 $\mu \mathrm{m}$ diameter cell bodies which are often elongated in the vertical axis (Fig. 5a). One to three major dendrites emerge from the cell body and branch into a simple dendritic tree stratifying high in the IPL in the equivalent of stratum 1. The overall dendritic spread does not exceed $150 \mu \mathrm{m}$ at this stage and the majority of dendrites end in growth cones (arrows, Figs. 1, 2b, and 3b). The most mature Toh + amacrines are found in the central area of the developing retina and a 

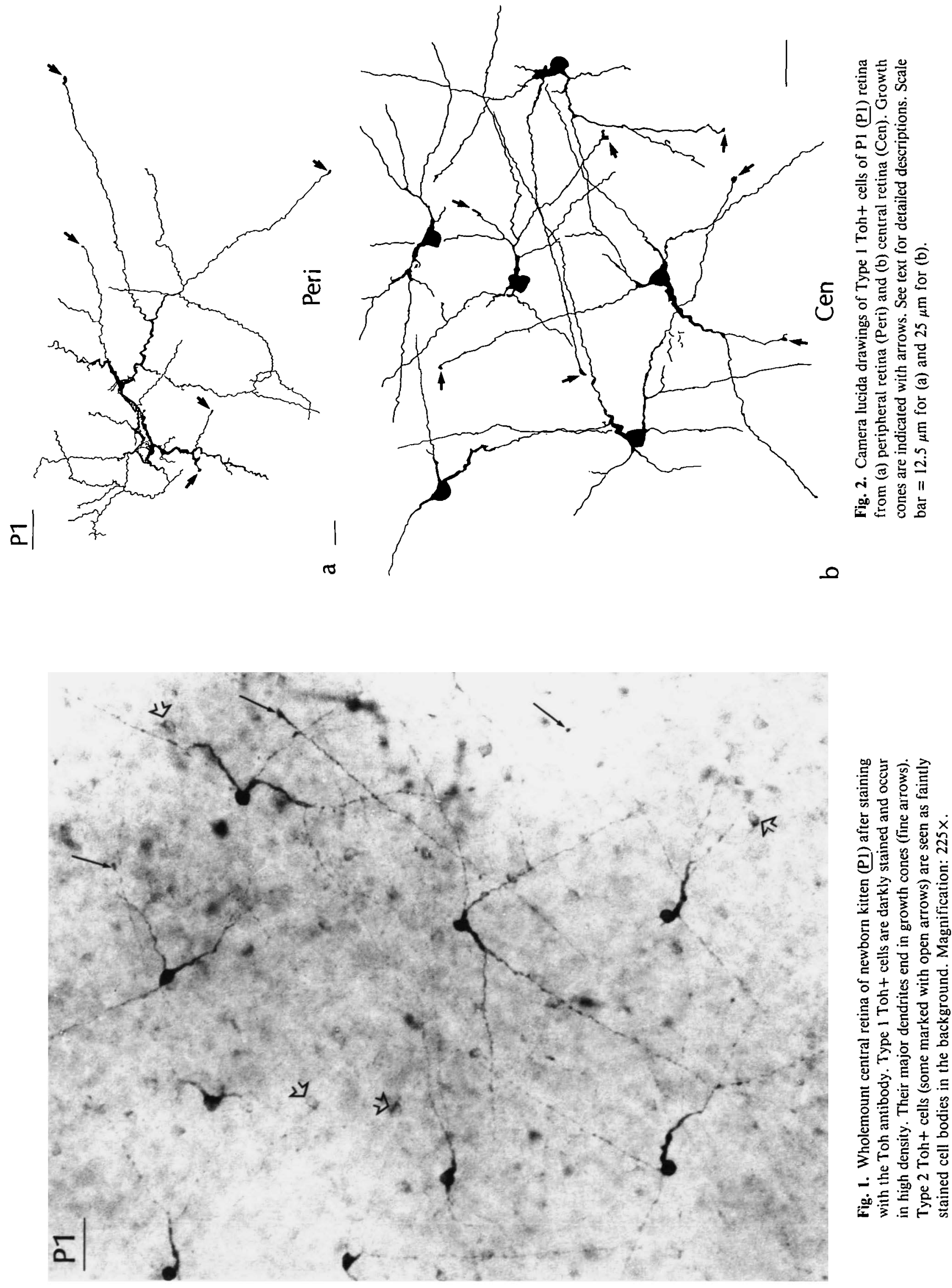

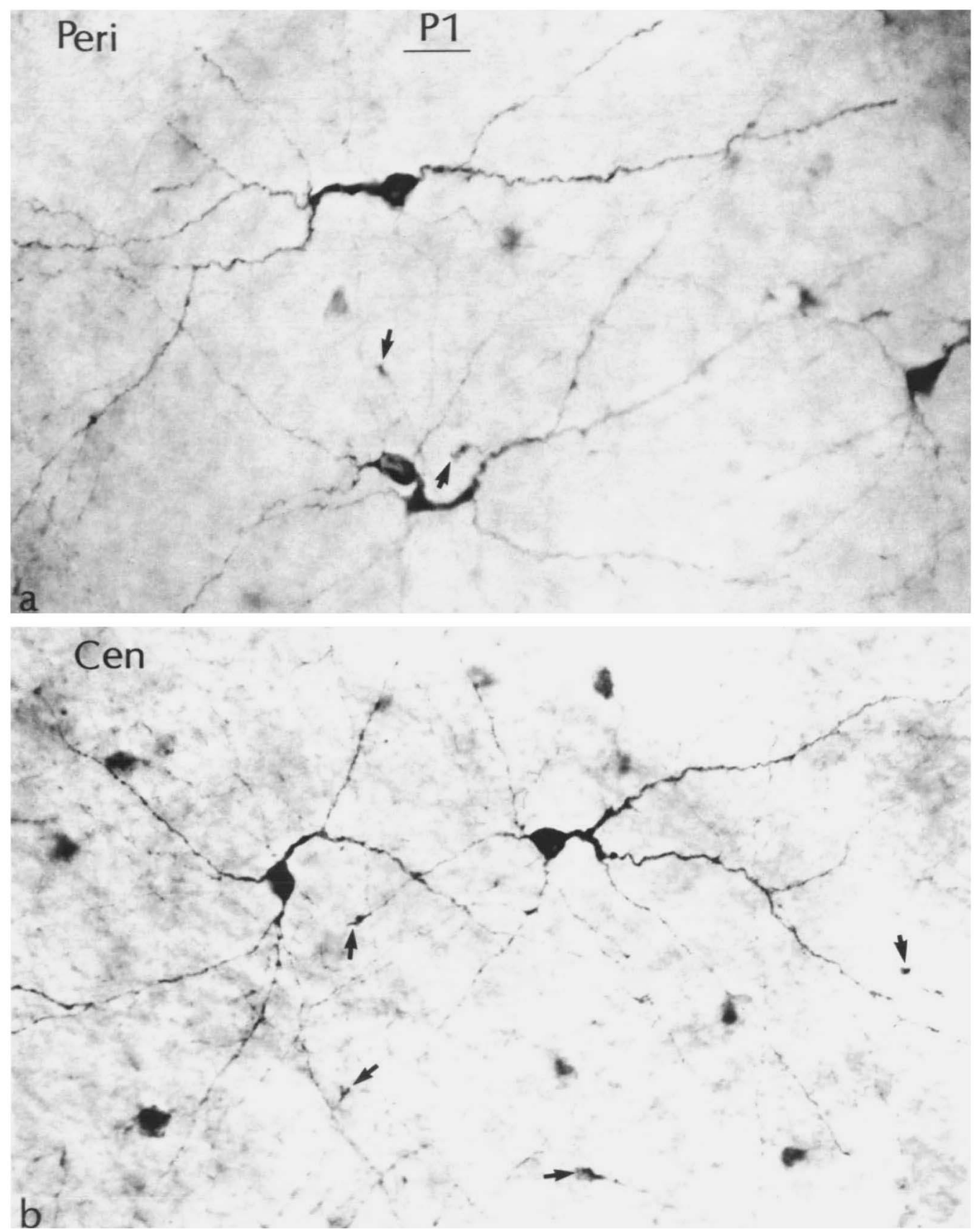

Fig. 3. Light micrographs of Type 1 Toh+ cells as seen in wholemount retina at $P 1(P 1)$ in (a) peripheral retina (Peri) and in (b) central retina (Cen). Growth cones are marked with arrows. Magnification for both (a) and (b): $450 \times$.

clear centro-peripheral gradient of maturity of the neurons can be seen. In peripheral retina, the Type 1 Toh + cells are much more primitive appearing than the more central cells (compare Figs. $2 a$ and $2 b, 3 a$, and $3 b$ ).

The least mature cells of peripheral retina are characterized by an irregular appearance and an exuberance of dendritic growth. Hence, the dendrites appear spiny with many hair-like processes and thickened pseudopodia-containing growth cones (Figs. 2a and 3a). Often the cell body of such immature Toh+ cells is off to one side of the single main dendrite even to the point that it is dislocated and joined only by the thinnest bridge to the enlarged main dendrite (Fig. 3a). The dendritic trees of the peripheral immature cells do not exceed $100 \mu \mathrm{m}$ and where the cells are developing at the ora serrata, the developing dendrites are oriented circumferentially.

In Fig. 4, an enlargement of the cell body and the primary dendrites of a central Toh+ Type 1 cell is shown. The main dendrites have an irregular shape due to their passing around neighboring cell bodies and, in addition, they exhibit some small and large appendages. Some of these (arrows, Fig. 4a) are the first elements of rings. A more complete ring is being formed on the cell illustrated in Fig. 4b (arrows). These two examples are the earliest suggestions of the rings of the adult retina that we saw in the $\mathrm{P} 1$ retinas. The more peripheral immature 


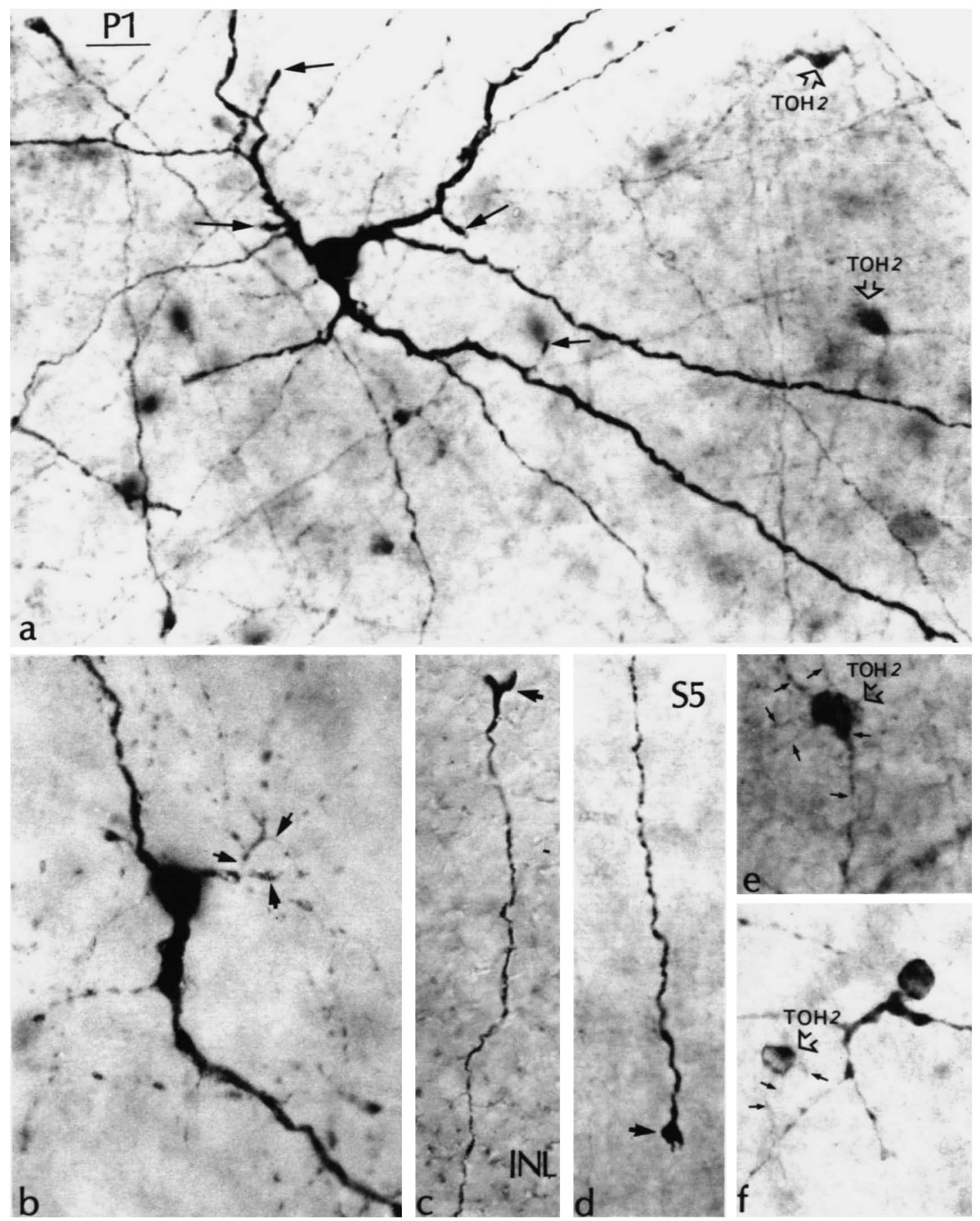

Fig. 4. Light micrographs of Toh + cells in $\mathrm{P} 1$ retina $(\mathrm{P} 1)$. (a) Type 1 Toh cells have spiny irregular main dendrites bearing small and large appendages (arrows). Type 2 Toh + cells (open arrows) are seen as faintly stained profiles. Magnification: $600 \times$. (b) A Type 1 cell of central retina exhibits early ring formation (arrows). Magnification: $750 \times$. (c) A Toh+ process ending in a growth cone (arrow) runs sclerad of the cell bodies and main plexus in the developing inner nuclear layer (INL). Magnification: $825 \times$. (d) A Toh+ process runs more vitread than the dendritic plexus in stratum 1 , in the equivalent of developing stratum 5 (S5). Magnification: $825 \times$. (e) Type 2 Toh + cell (open arrow) exhibits faint staining of its cell body and dendrites (small arrows). Magnification: $825 \times$. (f) Cell body and faint dendrites (small arrows) of Type 2 Toh + cells (open arrow) can be compared with the larger cell body and dendrites of an understained Type 1 cell. Magnification: 450x.

cells show no such specializations yet. However, we have noted the presence of long processes with growth cones, coming from the primitive $\mathrm{S} 1$ plexus, to run approximately $10 \mu \mathrm{m}$ above the plane of focus of the main plexus, in peripheral retina (Fig. 4c).
Presumably these processes are passing through the developing inner nuclear layer (INL) because the outer plexiform layer (OPL) is not yet formed in these areas of peripheral inferior retina (see Fig. 5b, showing a peripheral Type 1 Toh + cell in ver- 
tical section). In one instance, we noted a process with a growth cone, running $8 \mu \mathrm{m}$ further vitread in the INL than the developing stratum 1 plexus (Fig. 4d). This may be the first sign of the deep "axon-like" processes that eventually run in stratum 5 (S5) of the adult Toh+ cells.

Type 2 cells of $P 1$ retina are much more numerous than Type 1 cells but extremely poorly stained as compared to Type 1 cells. The most that can be discerned from examination of wholemount retina is a faint halo of stain around a clear nucleus of the cell body and a single descending dendrite that splits to give rise to short extents of understained branches stratifying in the center of the IPL (Fig. 4a, e, and f). In vertical section of $P 1$ retina, the size and branching pattern of Type 2 cells is more clearly seen in relationship to the better stained Toh+
Type 1 cells (Fig. 5a-d). The Type 2 cells have a much smaller cell body (7-9 $\mu \mathrm{m}$ diameter), and the dendrites appear to be monostratified in stratum 3 of the IPL (Fig. 5c). Displaced varieties of both Type 1 and Type 2 Toh + cells are seen in Pl retinas fairly commonly (Fig. 5d).

\section{Toh+ stained amacrine cells at postnatal days 6 and 10} (P6 and P10)

At P6, the Type 1 Toh + cells are showing a more mature appearance and the very primitive cells seen in the peripheral retina at Pl are no longer apparent. All of the Type 1 cells look similar to the central cells of the Pl stage. They have $13-\mu \mathrm{m}$ diameter cell bodies, two to four major dendrites, and a 200 $400 \mu \mathrm{m}$ dendritic tree diameter (Fig. 6a). Small appendages and
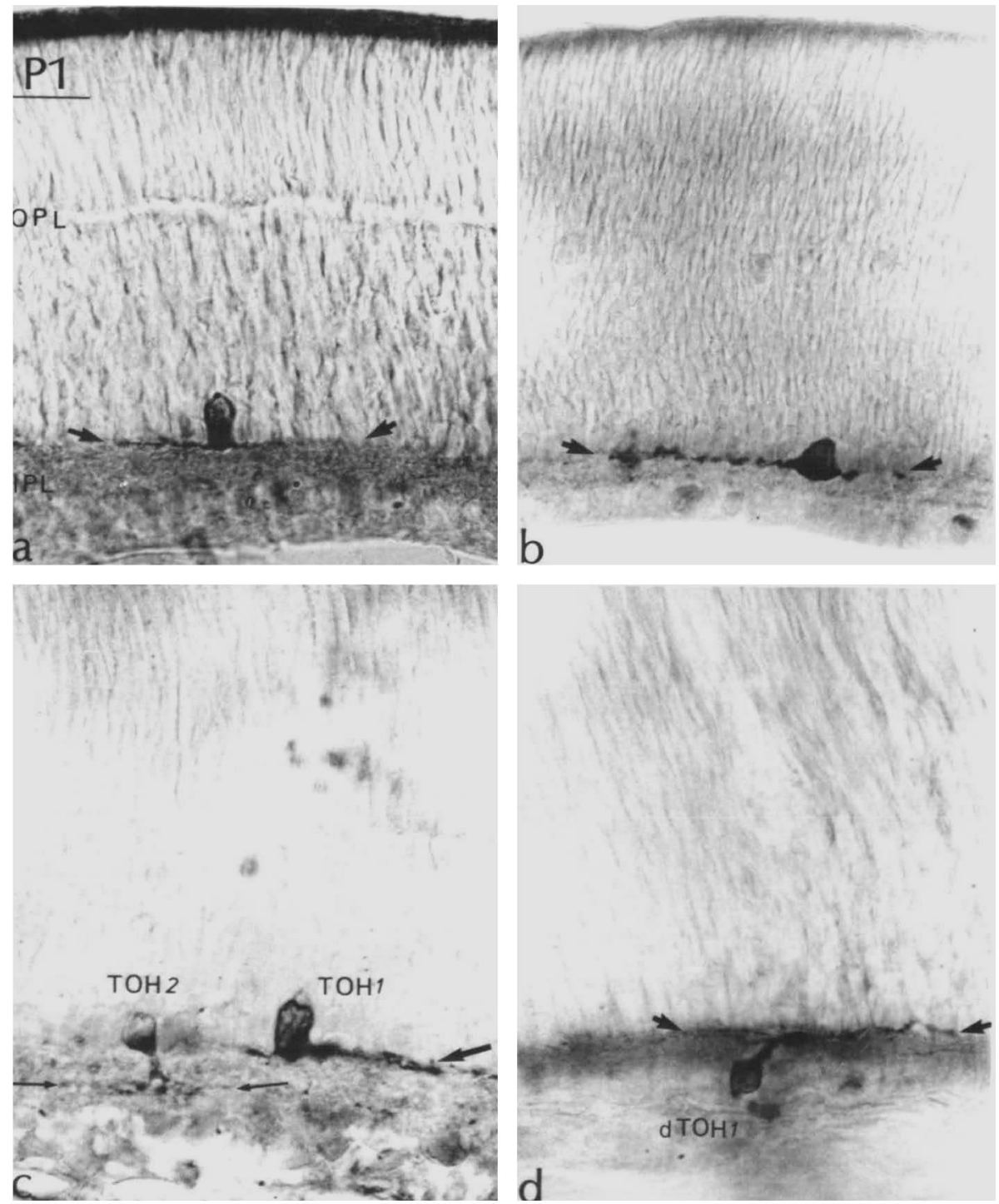

Fig. 5. Sectioned retina at $P 1(P 1)$ stage of development. (a) Toh+ Type 1 cell in central retina has a vertically elongated cell body and sparse dendritic branching in stratum 1 (arrows). The OPL and IPL are developing neuropils. (b) Type 1 Toh + cell of peripheral retina. There is no OPL in this region of retina yet. (c) Type 1 and Type 2 Toh + cells in central retina have different stratification for their dendrites, i.e., in stratum 1 for the former cell type (large arrow) and in developing stratum 3 for the latter cell type (fine arrows). (d) Displaced variety of Type 1 Toh + cell in peripheral retina. Magnification in (a)-(d): $450 \times$. 


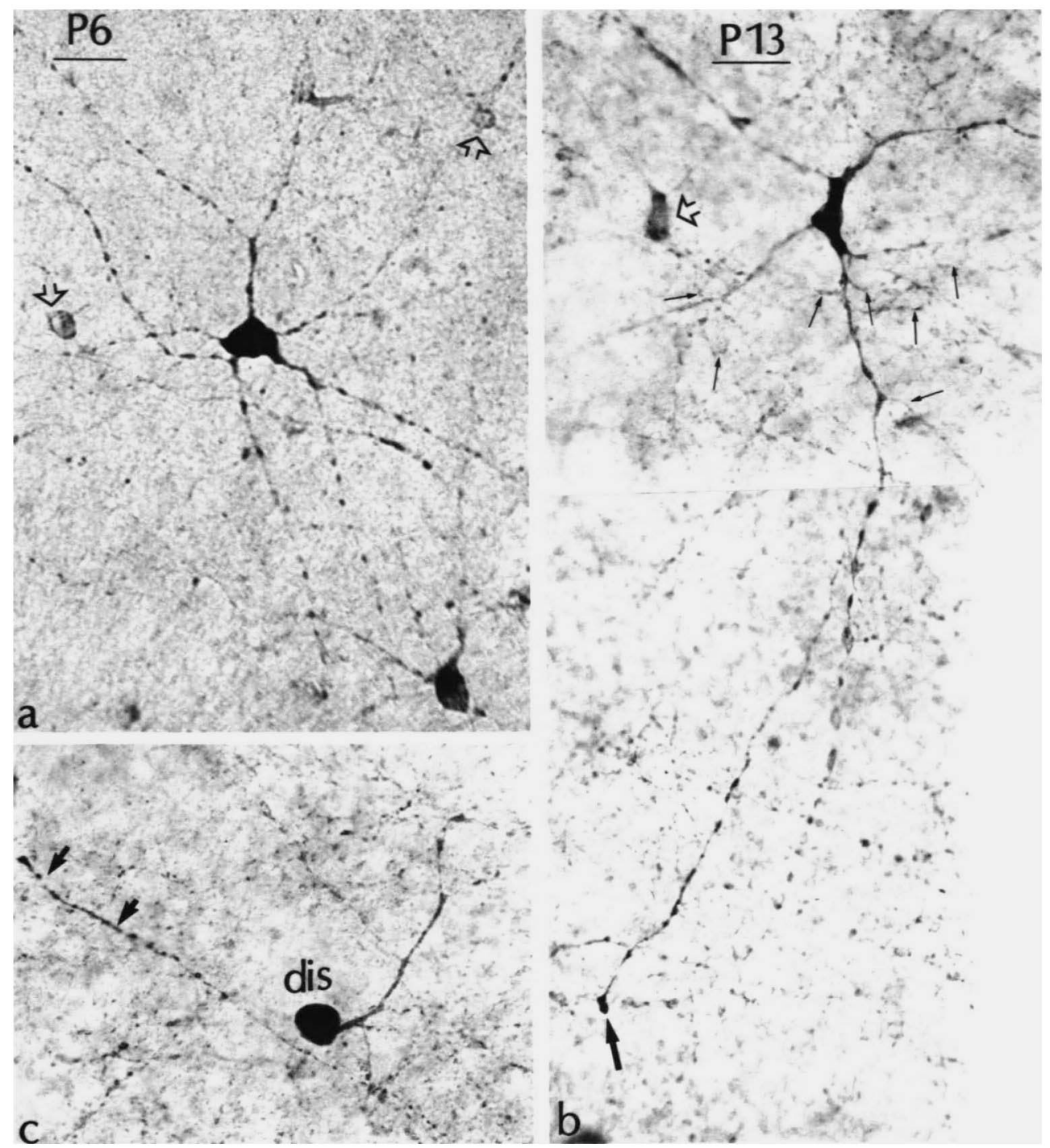

Fig. 6. (a) Type 1 Toh + cell are still poorly developed in peripheral retina from a P6 kitten (P6). Type 2 cells (open arrows) are seen in the background. (b) Type 1 Toh + cell of a P13 (P13) retina. The plexus of dendrites in stratum 1 is becoming more obvious and early rings are forming (small arrows) while some dendrites still end in growth cones (large arrow). Type 2 cells (open arrow) can still be seen occasionally. (c) A displaced cell body (dis) of a Type 1 Toh + cell from central retina of a P6 (P6) kitten. A long "axon-like" profile ending in a growth cone passes in stratum 5 at the same plane of focus as the cell body. Magnification in (a)-(c): $450 \times$.

branches are being added to the stratum 1 plexus of processes, but this plexus is still underdeveloped and scant (Fig. 6a, Fig, 7, and Fig. 8a, b). A few growth cones are seen on central cells but are more abundant on the cells of peripheral retina. In peripheral inferior retina, many processes with growth cones, apparently coming from the direction of the ora serrata, are criss-crossing in the more sclerad plane of focus than the cell bodies and the stratum 1 plexus. In sectioned retina at P6, we noted Type 1 Toh + cells occasionally exhibited thick processes emerging from the cell body to run towards the OPL (Fig. 8a, small arrows). These may be remnants of the original anchor to the outer limiting membrane or early "interplexiform-like" processes. In addition, occasional deeply running processes are seen (Fig. 6c, arrows). Type 2 Toh + cells are still visible in the background as faintly stained small cell bodies (Fig. 6a, b, open arrows).
Toh+ amacrine cells at postnatal day 13 (PI3)

At P13, the Type 1 Toh+ cells are developing many of the adult characteristics. The cell body is large, now averaging $15 \mu \mathrm{m}$ in diameter, and the dendritic tree is enlarged to the point that it is difficult to measure the boundaries of the field due to the peripheral dendrites disappearing into the plexus of dendrites interlaced in stratum 1. As can be seen in Figs. 6b, 8c, and 9a, Toh+ Type 1 cells of the central retina lie in a more clearly developed plexus in stratum 1 of the IPL, and rings typical of the adult are becoming defined (small arrows). Growth cones are still seen on some Toh+ stained dendrites (Figs. 6c and 9a, large arrows), and the deep stratum 5 processes are now becoming obvious. In inferior retina, the processes in the OPL are now seen occasionally, and they run for hundreds of microns in this layer. In peripheral retina, some very faintly stained Type 2 cells can still be seen (Figs. 6c and 8c, open arrows). 


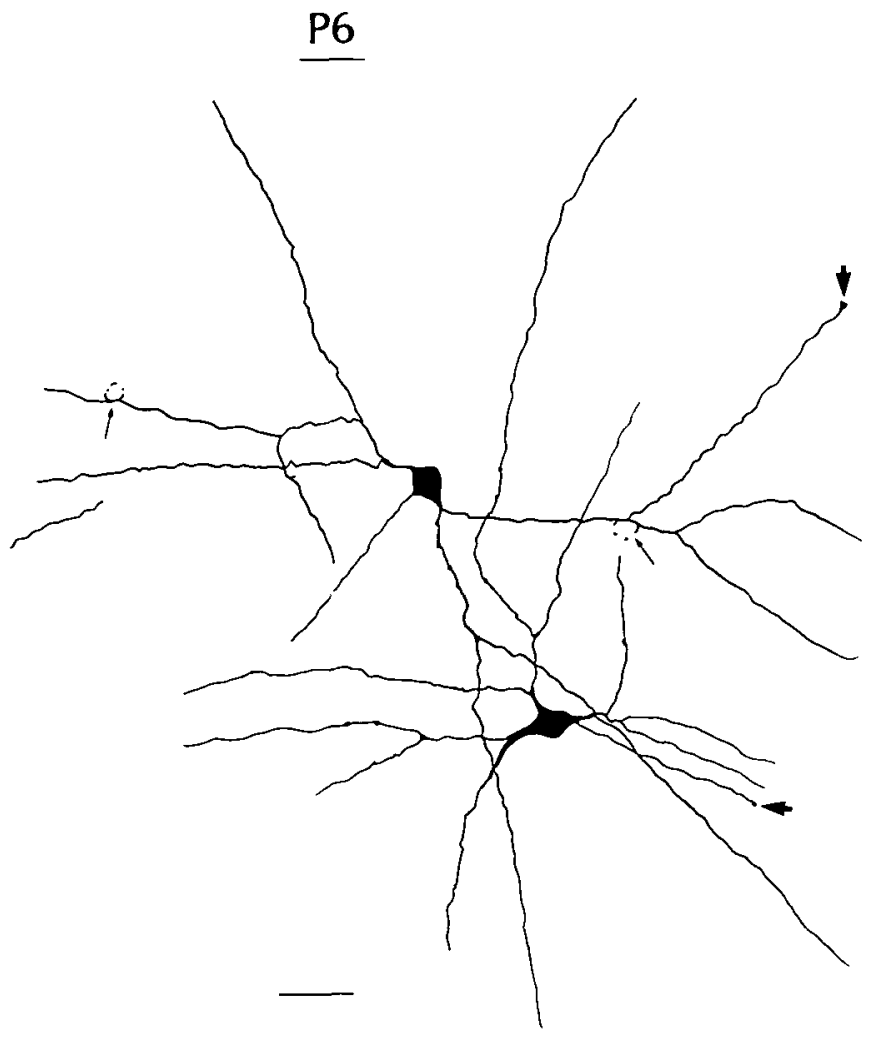

Fig. 7. A camera lucida drawing of Type 1 Toh+ cells of mid-peripheral retina in P6 kitten retina (P6). Growth cones are still present (large arrows) and early rings are forming (fine arrows). Scale bar $=25 \mu \mathrm{m}$.

Toh+ amacrine cells at postnatal days 20 and 30 (P20 and P30)

In the days between P20 and P30, the Type 1 Toh+ neurons are constantly adding dendritic processes to the plexus in stratum 1, so that the cells and the plexus have achieved adult morphologies by P30 (Figs. 9b and 10a). The cell bodies of Type 1 cells have now enlarged to $15 \mu \mathrm{m}$ in diameter. Moreover, the retina has grown and stretched such that the cells are more widely dispersed. In addition, the dendritic plexus is more clearly defined to stratum 1 because the full IPL thickness has been attained by this stage of development (Fig. 8d). Type 2 Toh + cells are now no longer visibly stained even in far peripheral retina. The main dendrites of Toh+ Type 1 cells are smoother than earlier stages of development, but they still conform to the shapes of neighboring cell bodies and their appendages have become the rings around amacrine cell bodies known to be AII and A17 types (Kolb et al., 1990) (Fig. 9b). By P30, the rings of the plexus are now completed by overlapping Toh+ dendrites from neighboring cells (Fig. 10a). Deep "axon-like" stained processes are present criss-crossing the neuropil in stratum 5 as can be seen in Figs. 10b and 10c, where a displaced Toh + cell body and main dendrite is in the same plane of focus as the thin process passing nearby (arrows). Other processes in stratum 5 , in a completely different plane of focus from the main plexus in stratum 1, are illustrated in Figs. $9 \mathrm{~b}$ and 10c. By P30, some Toh+ stained processes are seen running in the now fully developed OPL of inferior retina.
Quantitative aspects of developing Toh+ amacrine cells

\section{Total number and distribution of Type 1 \\ Toh+ amacrine cells}

Newborn kittens (P1) have a smaller eye than adult cats, of course, and the retina only measures some $15 \mathrm{~mm}$ across. The optic nerve is very small $(0.5 \mathrm{~mm}$ diameter $)$ and the blood vessels ill-defined. Counts of all of the Type 1 Toh+ cells stained reveal that there are approximately 4000 cells present in the retina at this stage (Table 1) and that the mean density is 30 cells $/ \mathrm{mm}^{2}$. Counts of the cells at P6, P13 after eye opening, and at P30, where full morphological maturity of the cells has been attained, indicate that the actual numbers of Type 1 Toh + cells remain about the same (Table 1). At $\mathrm{P} 13$, the retina measures $20 \mathrm{~mm}$ in diameter and contains approximately 4300 Type 1 cells at a mean density of 19 cells $/ \mathrm{mm}^{2}$, and at P30 the retina, at $26 \mathrm{~mm}$ diameter, contains 4500 Type 1 cells at a mean density of 18 cells $/ \mathrm{mm}^{2}$ (Table 1). We know from other authors' counts (Table 1) that the adult cat retina, which measures approximately $33 \mathrm{~mm}$ in diameter, contains between 3000 and $4300 \mathrm{Toh}+$ Type 1 cells, at a mean density of $9 / \mathrm{mm}^{2}$. Thus, most of the Type 1 Toh + cells appear to be already formed at birth.

The distribution of the Toh + type 1 cells at four different stages of development are illustrated in the isodensity maps of Fig. 11. As can be seen, the cells are crowded into the central retina of the smaller $P 1$ retina with a peak cell count of 55 cells $/ \mathrm{mm}^{2}$ in superior temporal retina at some distance from the developing area centralis (AC). Gradually during development, the retina enlarges and the cells become more evenly distributed in wide isodensity rings around the $\mathrm{AC}$ but with a subtle peak somewhere in the superior temporal region. The isodensity maps are difficult to draw because there is considerable variation from retina to retina. Thus, the maps of Fig. 11 represent the trend of the distribution dynamics of the Type 1 Toh + cells during development.

Table 1. Number of cells and mean density distributions of Toh + amacrine cells in the developing kitten retina

Cell number

Stage Total Toh+ cells Type 1 Toh + cells Type 2 Toh + cells

\begin{tabular}{lccr}
\hline P1 & 44,150 & 4,150 & 40,000 \\
P6 & 24,400 & 4,400 & 20,000 \\
P13 & 11,700 & 4,300 & 7,400 \\
P30 & 4,500 & 4,500 & 0 \\
Adult & $4,240^{\mathrm{a}}$ & $4,240^{\mathrm{a}}$ & 0 \\
& $3,366^{\mathrm{b}}$ & $3,366^{\mathrm{b}}$ & 0
\end{tabular}

Mean density $/ \mathrm{mm}^{2}$

$\begin{array}{lccr}\text { P1 } & 263 & 30 & 233 \\ \text { P6 } & 121 & 26 & 95 \\ \text { P13 } & 54 & 19 & 35 \\ \text { P30 } & 18 & 18 & 0 \\ \text { Adult } & 9^{\mathrm{a}} & 9^{\mathrm{a}} & 0\end{array}$

${ }^{a}$ Mitrofanis et al., 1988.

${ }^{b}$ Oyster et al., 1985. 

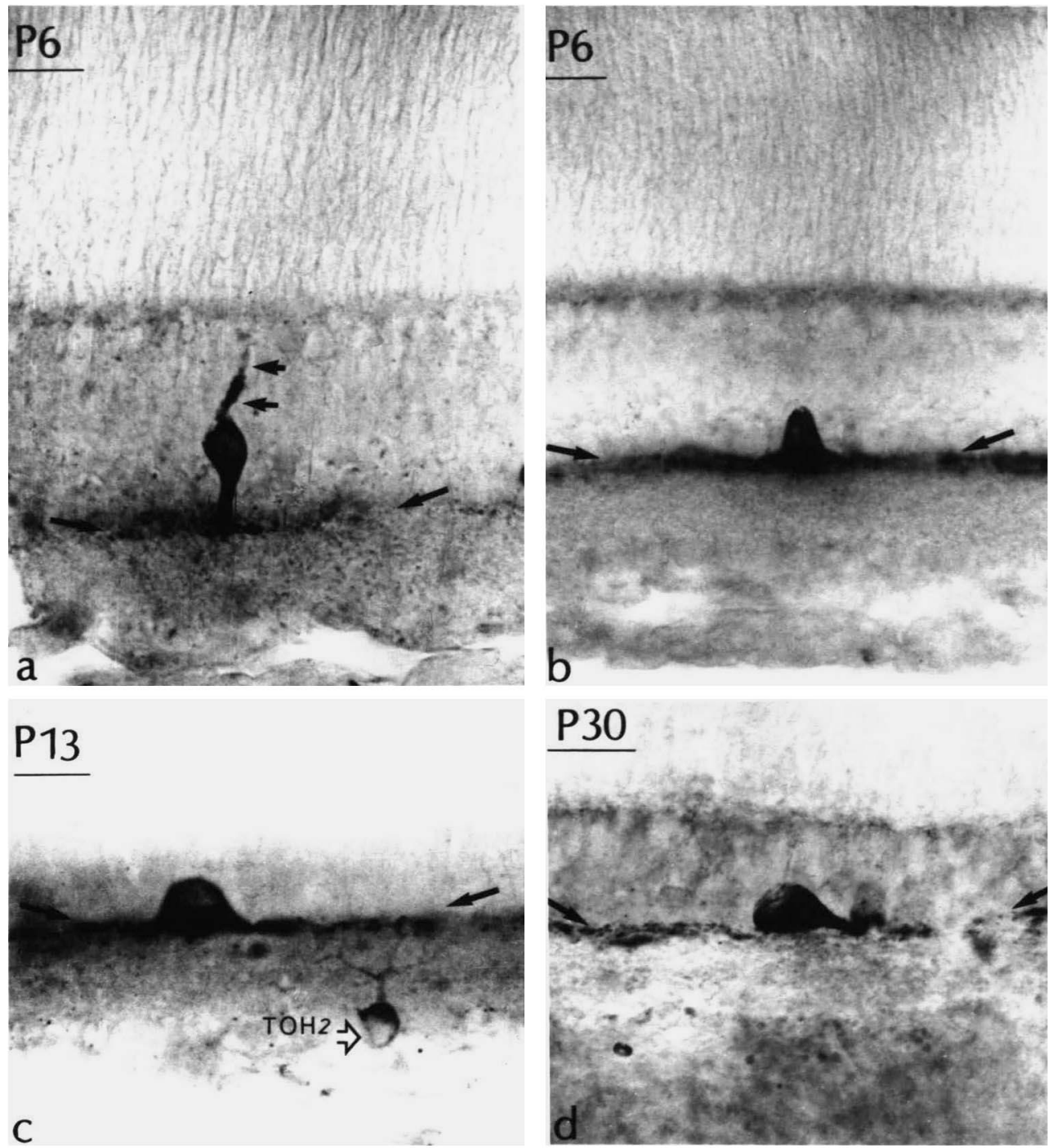

Fig. 8. (a, b) Vertical sectioned P6 (P6) peripheral retinas to show developing Type 1 Toh+ cells. The cell in (a) has a stout ascending process reaching up for the OPL ( 2 arrows). (b) The major dendritic plexus is in stratum 1 (arrows) of the IPL, but is not yet well-developed. (c) Type 1 Toh + cell in P13 retina (P13). The large cell is now the characteristic adult shape and the stratum 1 plexus is further developed. A type 2 (open arrow) Toh + cell is displaced to the ganglion cell layer. (d) The fully mature appearing Type $1 \mathrm{Toh}+$ cell at $30 \mathrm{~d}$ postnatal (P30). The plexus in stratum 1 (arrows) is almost completely mature. Magnification in (a)-(d): $525 \times$.

A comparison of the distribution patterns of Type 1 Toh+ amacrines to ganglion cells in the kitten retina, along the vertical and horizontal transects of the retina for the four developmental stages, is shown in Figs. 12a and 12b. The distribution of the ganglion cells is taken from Mitrofanis and co-workers' (Mitrofanis et al., 1988) paper. As can be seen, the distribution of the Type 1 Toh + cells in newborn and P6 kittens retina is peaked at 40-55 Toh+ cells $/ \mathrm{mm}^{2}$, in temporal superior retina 2-4 $\mathrm{mm}$ from the $\mathrm{AC}$, and because the retinas are so small at these stages, the central high density of cells is maintained to the near periphery of the retina. At the P1 stage, the attenuated staining of the developing primitive Toh+ cells of the far peripheral retina cause the counts to drop precipitously in these peripheral regions. In the older retinas, $\mathrm{P} 13$ and $\mathrm{P} 30$, the flat- ter distribution pattern of the adult retina becomes developed; however, the peak distribution of $25 \mathrm{Toh}+$ cells $/ \mathrm{mm}^{2}$ is still seen in temporal superior retina $2-3 \mathrm{~mm}$ from the $\mathrm{AC}$ (Fig. 12b).

\section{Number and distribution of Type 2 Toh + cells}

Type 2 Toh + amacrine cells stain very faintly as can be seen in the micrographs of Figs. 3 and 4, so that it is difficult to assign them a morphological identity. However, their cell bodies are stained well enough to allow them to be counted. Figure 13 shows the distribution pattern of the small Toh + Type 2 cells in retinas from P1-P30 from counts made on the vertical and horizontal transects of the retina centered on the developing AC. During the first 2 weeks postnatally, very large numbers of Type 2 cells stain with the Toh+ antibody in central and pe- 


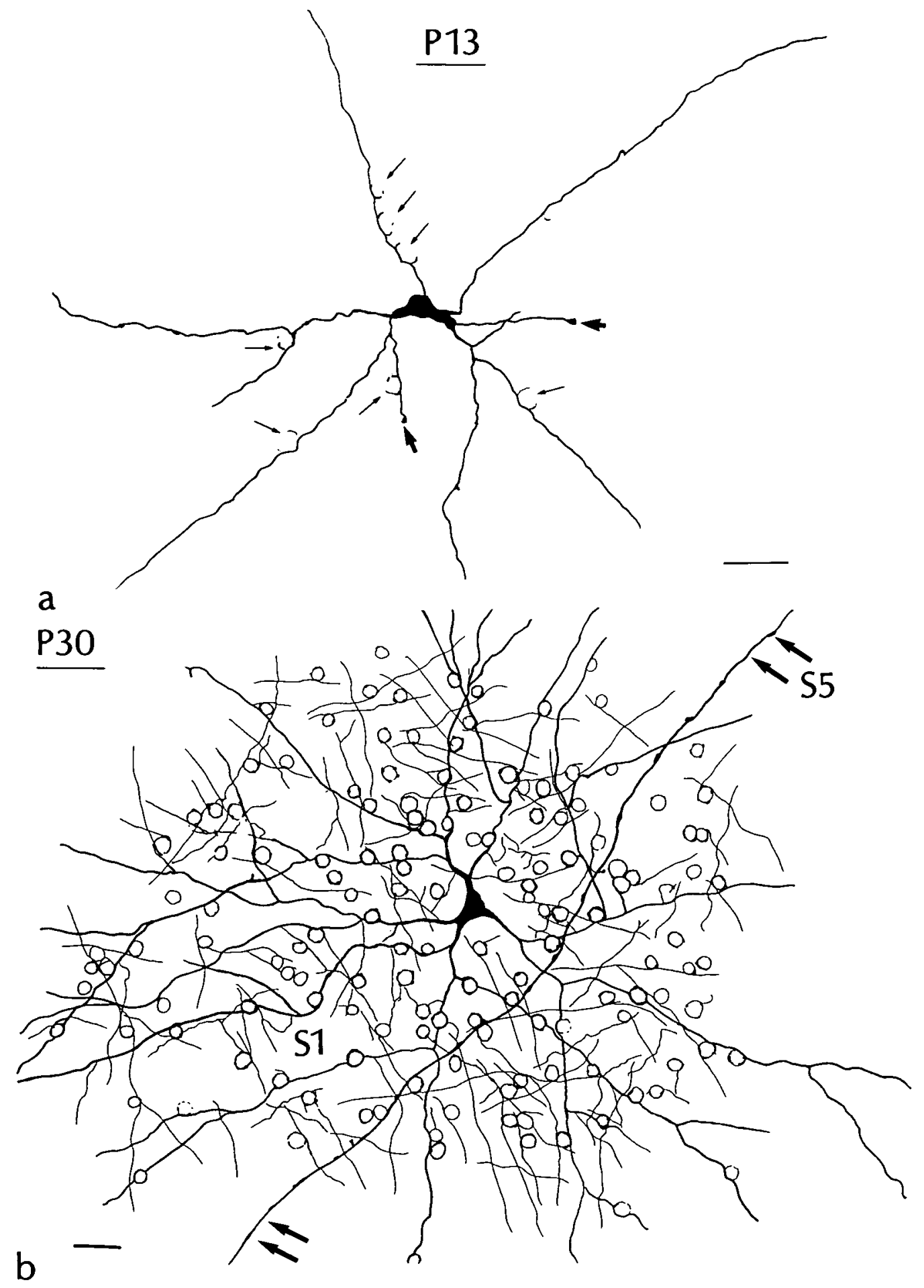

Fig. 9. (a) Camera lucida drawing of a Type 1 Toh + cell at P13 ( 13 ). Occasional growth cones are still seen (large arrows) and the rings are forming on the dendrites (fine arrows). Scale bar $=25 \mu \mathrm{m}$. (b) A Type $1 \mathrm{Toh}+$ cell at P30 (P30). The cells have the mature adult appearance with a large dendritic tree hidden in a plexus of overlapping neighboring dendrites and rings in stratum 1 (S1). Deep "axon-like" processes run in stratum 5 (S5) (arrows). Scale bar $=25 \mu \mathrm{m}$.

ripheral retina (Fig. 13). After P13, they become increasingly more faintly stained and can only be counted in far peripheral retina. By P30, these cells no longer stain with the antibody (Fig. 13). Table 1 shows the actual numbers of Type 2 Toh + cell bodies that could be counted at the different postnatal stages.
The count of 40,000 Toh+ Type 2 cells at Pl suggests that this is at best an underestimate of a population of amacrines that remain at minimum this number into adulthood. Presumably, these cells' content of Toh + becomes masked or converted into some other neurotransmitter pathway by adulthood. 

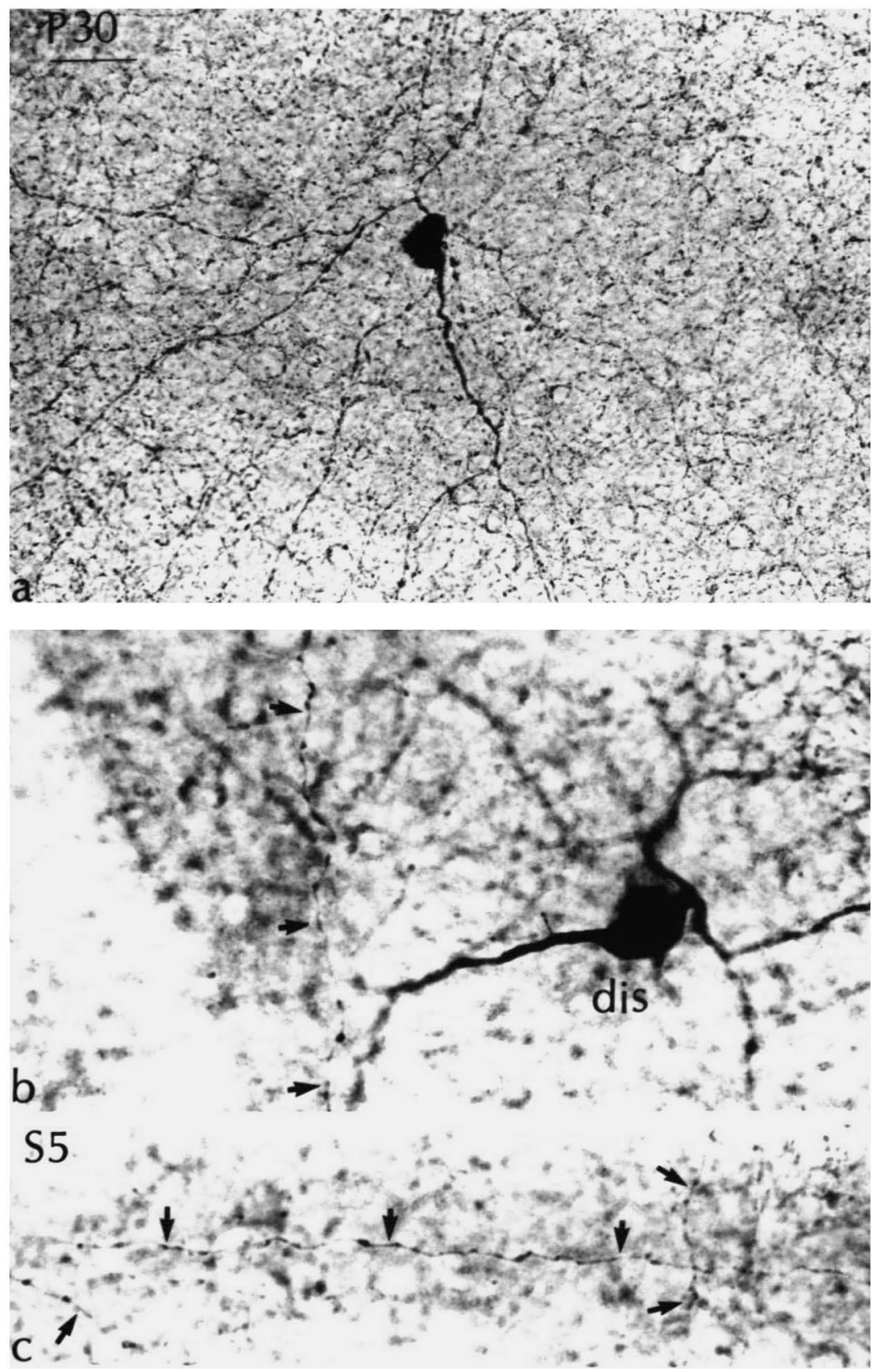

Fig. 10. (a) Fully mature Type 1 Toh+ cell of $P 30(P 30)$ kitten retina. The major dendrites and plexus of rings are fully developed. Magnification: 375x. (b) A displaced (dis) Type 1 Toh + cell to show that deep "axon-like" processes (arrows) run in the same plane of focus as the cell body in stratum 5 of the IPL. Magnification: 750x. (c) Deep "axon-like" processes run and cross (arrows) in stratum 5 (S5) of the IPL. Magnification: $750 \times$.

\section{Cell body sizes of Toh+ stained amacrines}

Measurements of cell body diameters were made on Toh+ stained cells in midperipheral regions of the retinas at four developmental stages, P1, P6, P13, and P30. The histograms of Fig. 14 demonstrate that two populations of cells, based on cell body diameters, were being stained in the early postnatal days. At P1, there was some difficulty in distinguishing two cell body size groups because at this stage both immature Type 1 and Type 2 cells had their greatest ranges of size and thus overlapped at the $11-\mu \mathrm{m}$-diameter range. However, the two cell types were easily distinguished by their intensity of immuno- staining. At P6 and P13 stages, the Type 1 and Type 2 cells were easily distinguished on cell body diameter, with the apparent enlargement of the Type 1 cell bodies to reach the adult size of approximately $15.5 \mu \mathrm{m}$ diameter (Fig. 14). Cell body sizes of the Type 2 cells were always smaller (mean diameter at all stages was $9 \mu \mathrm{m}$ ). The larger cell bodied population, i.e. Type 1 cells, was the only population remaining by P30 (Fig. 14).

\section{Discussion}

Using an antibody to tyrosine hydroxylase, the first enzyme in the synthetic pathway for the catecholamine dopamine, we have 

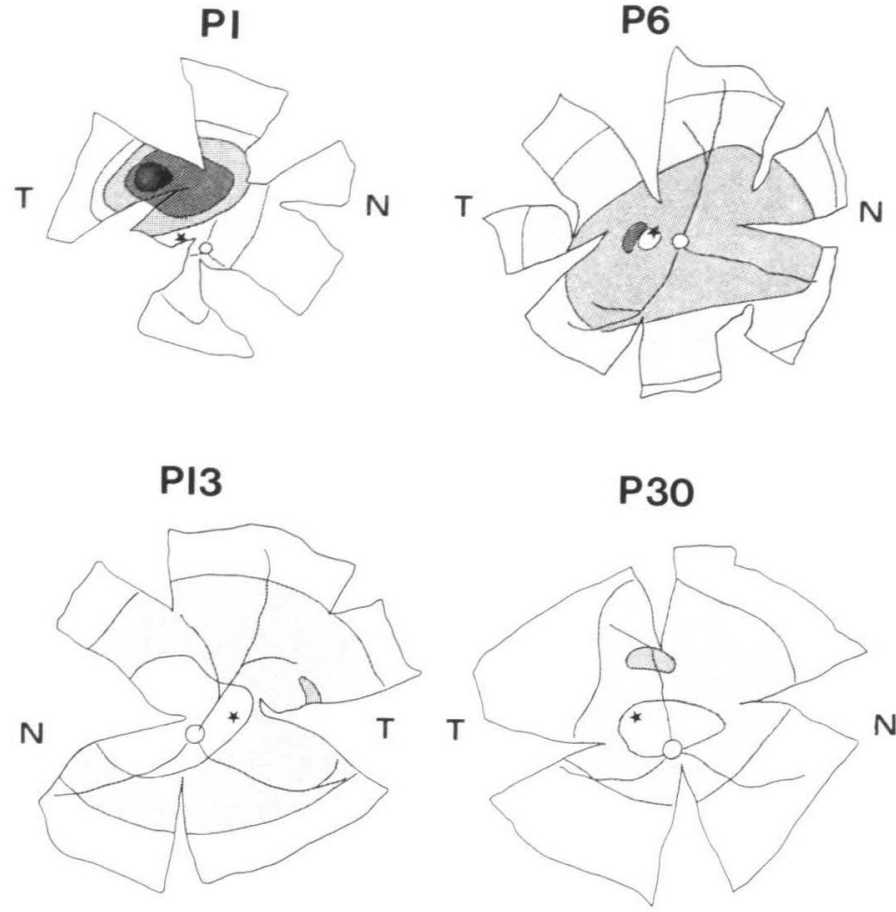

$\underline{4 \mathrm{~mm}}$

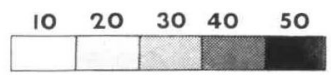

Fig. 11. Isodensity maps of the distribution of Type 1 Toh + cells in the retinas of kittens at developmental stages P1, P6, P13, and P30. Temporal $(\mathrm{T})$ and nasal $(\mathrm{N})$ retina are indicated and the retinas are all drawn with superior retina to the top. The density key indicates number of cell $/ \mathrm{mm}^{2}$. The peak density at $\mathrm{P} 30$ is $25 \mathrm{cell} / \mathrm{mm}^{2}$. The location of the $\mathrm{AC}$ is denoted by the star.

stained the dopaminergic amacrine cells of the kitten retina, and followed their morphological changes during development from primitive immature cells at postnatal day 1 to the fully developed amacrine cells and plexus of dendrites typical of the adult cat at postnatal day 30 . The full complement of dopaminergic amacrine cells appear to be present already at birth because the number of Type 1 Toh+ cells that become A18 (Kolb et al., 1981) dopaminergic amacrine cells does not change significantly between P1 and P30. Moreover, the total number of Type 1 dopaminergic cells in kitten retinas at P30 is not appreciably different from the number of dopaminergic amacrine cells in adult cat retinas reported by others (Mitrofanis et al., 1988; Oyster et al., 1985) (see Table 1). A second population of amacrine cells also stains transiently with the tyrosine hydroxylase antibody. These cells, herein called Type 2 Toh + cells, have smaller cell bodies, different dendritic stratification, and are a larger and a higher density population than the Type 1 dopaminergic amacrines. Type 2 amacrine cells are only Toh positive for the first $20 \mathrm{~d}$ of the kitten's retinal development.

\section{Morphology and synaptogenesis of dopaminergic amacrine cells}

The development of the fully mature Type 1 dopaminergic amacrine cell with the characteristic dendritic plexus stratifying in stratum 1 of the IPL occurs gradually over the course of the first $30 \mathrm{~d}$ postnatally. Before the eyes open at P10, the dendrites of this amacrine cell type are clearly immature and most of them exhibit large growth cones. However, cells of the central retina, where development proceeds earliest, have many appendages which are clearly looping around neighboring amacrine cell bodies as the first signs of the Toh+ or fluorescent rings seen in the mature adult dendritic plexus. Even at $\mathrm{P} 1$, dopaminergic cells of the central retina exhibit early rings from dendrites within a few microns of the cell body (Fig. 4b). By following the formation of the rings over the course of the first 30 d, we can see that the rings are formed primarily from dendritic appendages borne on the major dendrites of individual dopaminergic amacrine cells before neighboring cells dendrites invade their retinal space. However, we cannot exclude the possibility that boutons of finer dendrites of neighboring cells may contribute to some of the rings eventually. As more and more dendrites are added to the maturing cells, the dendritic trees begin to overlap and the complete plexus of tightly packed rings in stratum 1 is gradually formed. We have belabored this point concerning ring formation because a recent theory has suggested that the rings of the dopaminergic amacrine cells are formed solely from end boutons of "axon-like" processes coming from cells millimeters away in the retina (Dacey, 1988). According to our findings, the rings are clearly not formed this way. In fact, it is almost certain that the cell described by Dacey (Dacey, 1988, 1989) as being the dopaminergic amacrine cell of the cat retina is not the Type 1 Toh + cell described in this and other studies (Kolb et al., 1990; Oyster et al., 1985; Voigt \& Wässle, 1987) at all.

The postnatal morphological development of dopaminergic neurons has been studied in rat (Nguyen-Legros et al., 1983; Savy et al., 1989), guinea pig (Parkinson et al., 1985), mouse (Wulle \& Schnitzer, 1989), and rabbit (Lam et al., 1981). The developmental history in these mammalian species is closely similar to what we have observed in the kitten. Toh+ immunoreactive cells can be discerned at $\mathrm{P} 1$ or $\mathrm{P} 3$ at the earliest; the development of the dendritic plexus does not proceed until after eye opening and is only completely developed after 3-4 weeks, dependent on the species. In the rabbit retina, we have the most complete descriptions of dopamine development as a neurotransmitter from measures of high-affinity uptake, synthesis, storage, and $\mathrm{K}+$ stimulated release at various postnatal intervals. Thus, we know in the rabbit that retinal tyrosine hydroxylase is very low in the stages P1-P6. If it is similar in the newborn kitten retina, this would coincide with our findings of immature appearing Toh+ with poorly developed dendritic trees still exhibiting many growth cones indicative of active addition to their dendritic trees, at these stages. At P18 in rabbit, there is a rapid increase in Toh levels to reach the adult level at P25. This would presumably coincide with the maturing of the dopaminergic cells and the completion of the dendritic network of rings in the stratum 1 plexus, by mid P20-P30, that we have observed in this study.

Glycinergic and GABAergic amacrine cells, in terms of uptake, synthesizing enzymes, and release under physiological conditions, are apparently mature earlier than dopaminergic amacrine cells in the rabbit retina (Kong et al., 1980; Lam et al., 1980). The primary GABAergic and glycinergic amacrine cells of the rabbit and cat retinas are A17 and AII amacrine cells, respectively, of the rod system pathways in the IPL. Although both these amacrines may be maturing in early postnatal days, they must await their input circuitry from rod bipolar cells be- 
VERTICAL TRANSECT

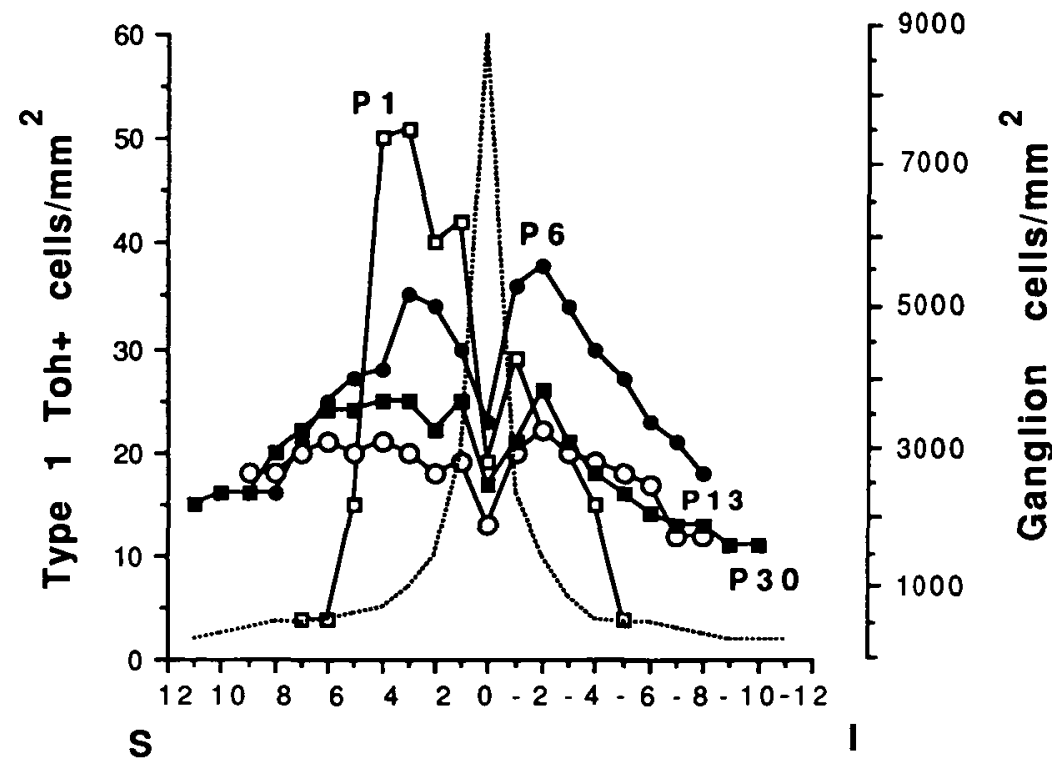

a

HORIZONTAL TRANSECT

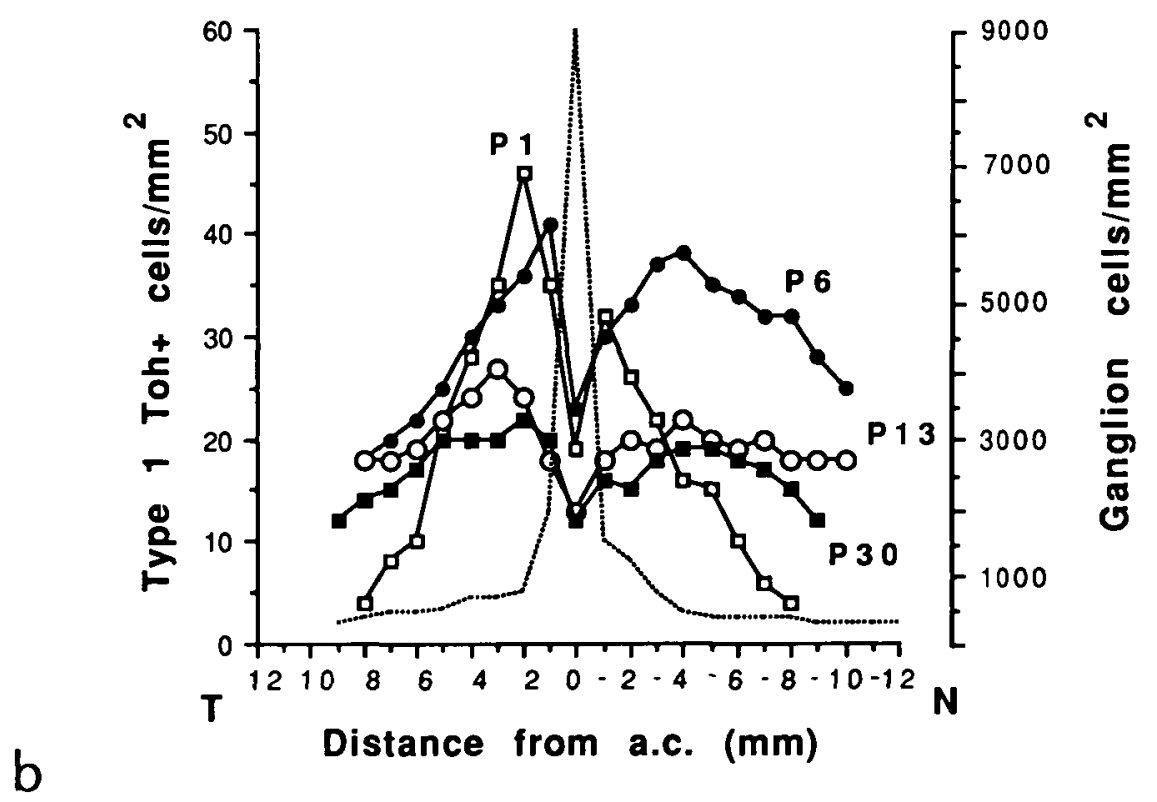

Fig. 12. Graphs showing the distribution of Type 1 Toh + cells along the vertical (a) and horizontal (b) transects of the developing kitten retina at ages P1 (open squares), P6 (filled circles), P13 (open circles), and P30 (filled squares). The counts were made at $1-\mathrm{mm}$ intervals along the transects centered on the estimation of where the developing area centralis $(0$ point $)$ would be. The plot of the ganglion cell peak at the AC (dotted line, scale on right) of the kitten retina is taken from Mitrofanis et al. (1988).

fore they can perform internuncial functions in rod signal transmission (Famiglietti \& Kolb, 1975; Kolb \& Famiglietti, 1974; Kolb \& Nelson, 1983; Sterling, 1983; Sterling et al., 1988). Indirect evidence suggests that rod bipolar synapses to amacrine cells develop a little later than cone bipolar synapses to ganglion cells. Electron-microscopical studies of the developing IPL suggest that the first-seen bipolar ribbon synapses occur in sublamina $a$, where only cone bipolars end, from P1-P6, while ribbon synapses in sublamina $b$, where rod bipolar axons synapse, in- crease dramatically between days P9-P11 in rabbit (McArdle et al., 1977) and probably cat too (Crooks \& Morrison, 1989; Morrison, 1982). Thus, it is reasonable to assume that the glycinergic AII and the GABAergic A17 amacrine cells of the rod pathways become activated only around the time of eye opening coincident with full maturity of their input synapses and neurotransmitter mechanisms. Extrapolating from rabbit to kitten retina suggests then that modulation of these circuits by dopamine arrives a little later over the next $10 \mathrm{~d}$ while the do- 


\section{VERTICAL TRANSECT}

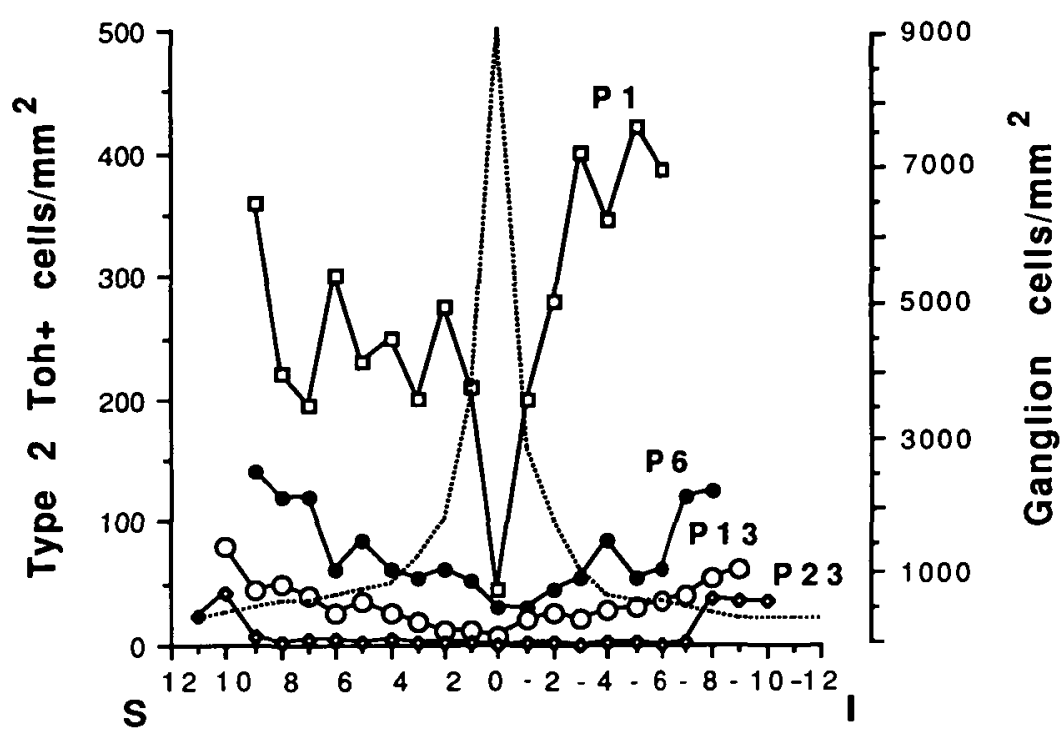

HORIZONTAL TRANSECT

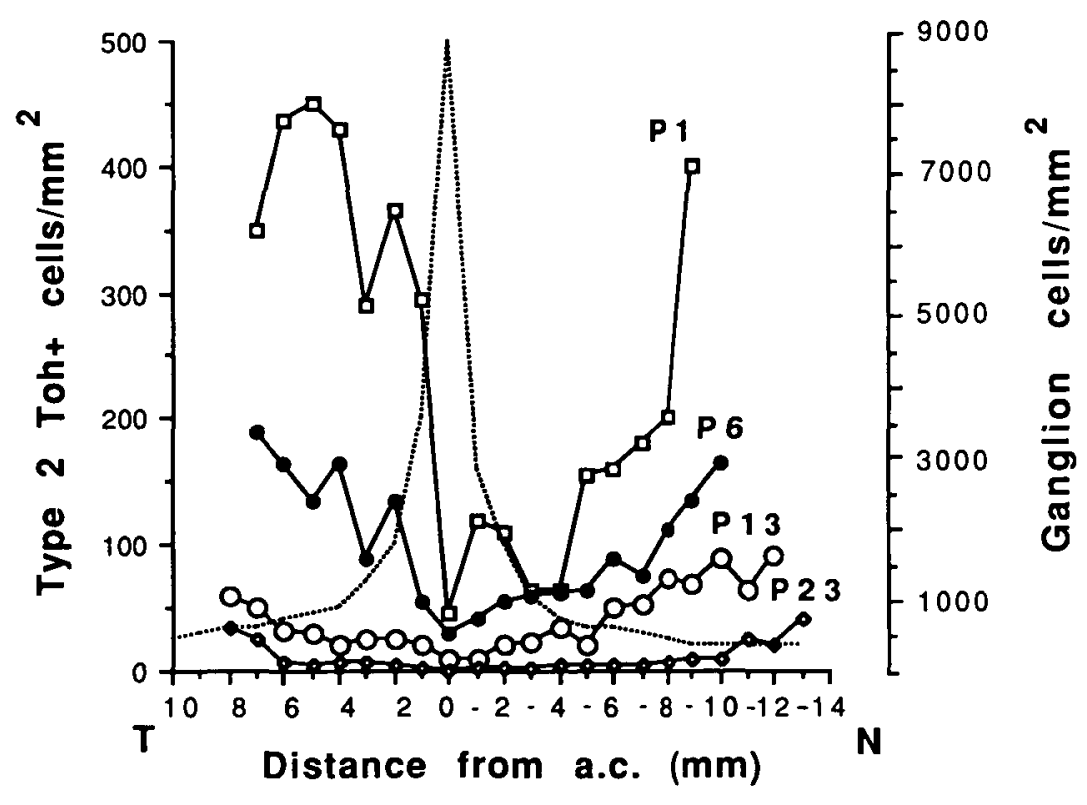

Fig. 13. Graphs showing the distribution of Type 2 Toh + cells along the vertical (a) and horizontal (b) transects of the developing kitten retina at ages P1 (open squares), P6 (filled circles), P13 (open circles), P23 (open diamonds). The counts were made at $1-\mathrm{mm}$ intervals along the transects centered on the estimation of where the developing area centralis ( 0 point) would be. The plot of the ganglion cell peak at the AC (dotted line, scale on right) of the kitten retina is taken from Mitrofanis et al. (1988).

paminergic plexus of ring contacts are being established upon the AI7 and AII cells (Kolb et al., 1990; Pourcho, 1982; Voigt \& Wässle, 1987).

A proportion of dopaminergic amacrine cells found in inferior retina of the adult cat have "interplexiform cell-like" attributes. These dopaminergic amacrines have processes arising from the cell body, or more commonly, from the stratum 1 plexus, to pass through the inner nuclear layer (INL) to the outer plexiform layer (OPL) to run therein for hundreds of microns (Kolb et al., 1990; Oyster et al., 1985). We have recently shown by an electron-microscopical study that these
Toh+ processes are presynaptic to the GABAergic interplexiform cell in the OPL (Kolb et al., 1990) indicating yet another link between dopaminergic and GABAergic systems in the cat retina. We took particular note of the course of development of these Toh+ processes running in the OPL in the present study. Although we saw a few Toh+ processes with obvious growth cones running through the developing INL in peripheral inferior retina at $\mathrm{P} 1$, there were a great many more at the P6 stage. These processes were probably not in the OPL at this stage of retinal development for they ran only $10 \mu \mathrm{m}$ vitread to other processes in the IPL. By P13, however, the OPL is definitely 

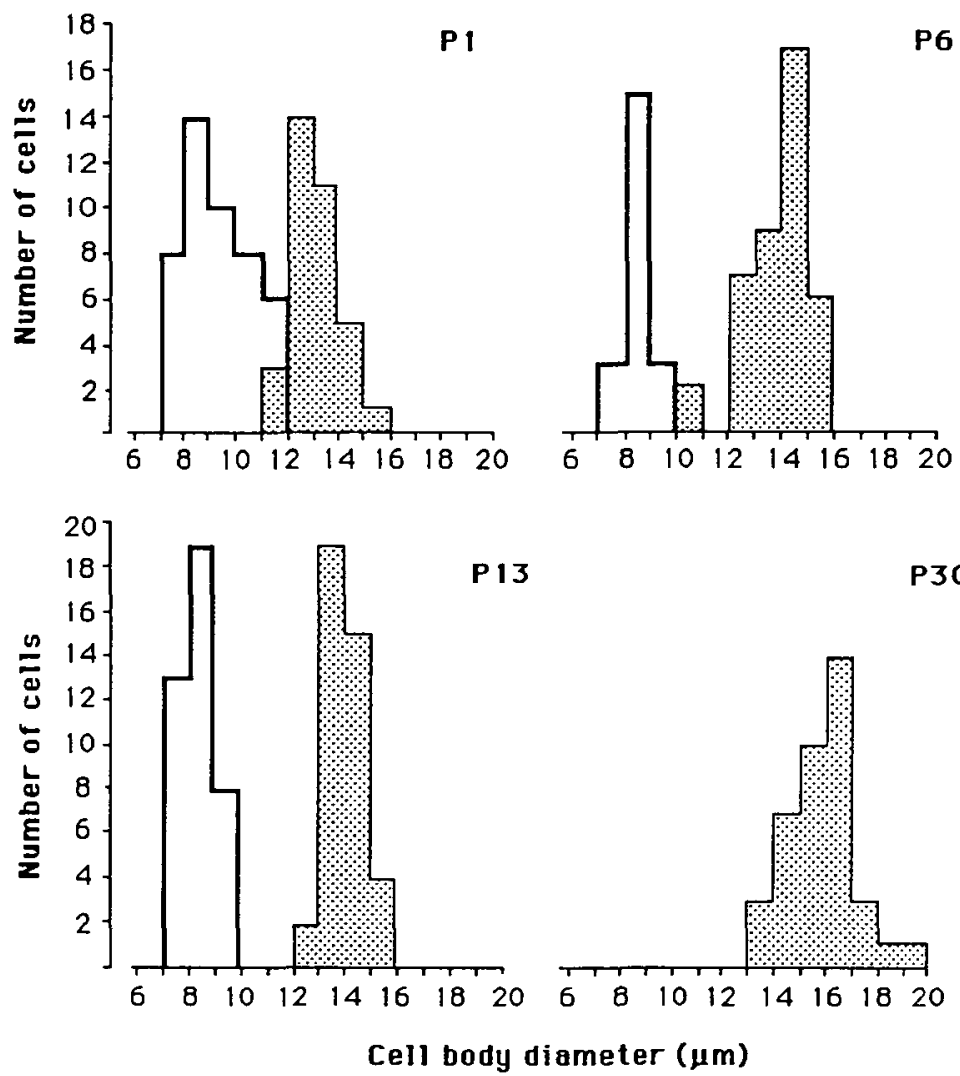

Fig. 14. Histograms to show cell body diameters of Toh-stained amacrine cells at P1, P6, P13, and $P 30$ of kitten retinal development. During P1-P13, two groups of cells can be distinguished on cell body diameters, but by P30 only one group remains. The smaller-sized cell body group (mean diameter $9 \mu \mathrm{m}$ ) contains Type 2 Toh + cells. The larger cell body group (stippled histogram) (mean diameter 14-15 $\mu \mathrm{m}$ ) is the Type $1 \mathrm{Toh}+$ or dopaminergic (A18) amacrine cell of the cat retina.

formed in inferior peripheral retina and the "interplexiform like" processes are likely to be searching for their targets for synaptic output in this layer. It is possible that the earlier seen Toh+ processes with growth cones were passing over the vitread surface of developing GABAergic interplexiform cells, and we would predict that the latter neurons have established synapses upon bipolar cell dendrites (Kolb \& West, 1977) in the OPL just after eye opening at P13, and that the Toh + processes are now following their target neurons' ramifications in the OPL.

Our observations on the development of the deep "axonlike" processes of Toh+ amacrines than run in stratum 5 indicate that they follow closely the time course of development of the OPL-directed processes. Although Toh+ processes bearing growth cones, running closer to the ganglion cells, are seen as early as $\mathrm{P} 1$ and $\mathrm{P} 6$, these processes cannot be forming synapses upon their target AII amacrine dendrites until the latter are in position postsynaptic to rod bipolar axon terminals. From the evidence mentioned above (Crooks \& Morrison, 1989; McArdle et al., 1977), it is most likely that rod bipolar axons form ribbon synapses to postsynaptic AII and A17 amacrines coincident with eye opening in the cat retina.

\section{Distribution of developing dopaminergic amacrine cells}

The findings of this paper suggest that commitment to become dopaminergic amacrine cells occurs before birth in the cat retina because at $P 1$ the full number of cells found in the adult retina are present (Table 1). Furthermore, our counts and mapping of Toh+ stained cells at birth show the peak density to occur 2-3 mm superior temporal to the developing $\mathrm{AC}$ much the same as is found in P30 retinas and in the adult cat retina (Mitrofanis et al., 1988; Oyster et al., 1985). The dopaminergic amacrines are more densely packed into the smaller area of newborn kitten retina, but over the course of the first $30 \mathrm{~d}$ they become spread further apart and the adult spacing and density distribution becomes achieved. There is evidently even more stretching or addition to peripheral retina going on beyond P30 until the adult full-sized retina is achieved ( $33 \mathrm{~mm}$ diameter) with the characteristic low mean density of 9 cells $/ \mathrm{mm}^{2}$ (Table 1).

Although the peak density of dopaminergic cells in the central retina subsides considerably from postnatal day 1 to adult retina, i.e. from around 55 cells $/ \mathrm{mm}^{2}$ at $\mathrm{P} 1$ to 20 cells $/ \mathrm{mm}^{2}$ in the aduit, it is still retained at a position $2-3 \mathrm{~mm}$ superior temporal to the AC. This peak does not coincide with the ganglion cell peak at the AC of course (see Fig. 12). The latter coincidence is not really expected because dopaminergic amacrine cells are known to have no direct synaptic relationship with ganglion cells in the cat (Hokoc \& Mariani, 1988; Kolb et al., 1990; Voigt \& Wässle, 1987). However, they are known to be very involved with the AII amacrine cell of the rod system. It would therefore be more reasonable to expect the peak density of dopaminergic amacrines to coincide with the peak of AII distribution. There is no coincidence here either, however, since the AII amacrine cells, like the ganglion cells, peak in the AC (Vaney, 1985). The only coincidence of dopaminergic cells peak density with any other retinal neurons, that we know of so far, 
is with the rod photoreceptors peak at 2-3 mm superior temporal to the AC (Steinberg et al., 1973). The same coincidence of peaks of rod photoreceptors and dopaminergic amacrine cells was noted for the rhesus monkey (Mariani et al., 1984).

\section{Transient Toh+ staining of a second amacrine cell population}

The amacrine cells that stain transiently with Toh antibodies over the first $20 \mathrm{~d}$ of kitten postnatal life, herein called Type 2 Toh+ cells, are an extremely numerous group (estimated to be about 40,000 Type 2 cells stained at P1, Table 1). Either these cells are a single population of a commonly occurring amacrine in the cat retina or they are a number of different classes of amacrine cell. The poor staining of their dendrites made it impossible to classify these Type 2 cells with any of the known Golgi-stained classes (Kolb et al., 1981). Clearly their morphology was different from the dopaminergic A18 cell type in their being significantly smaller-bodied (Figs. 5c, 8c, and 13) and appearing to stratify lower in the IPL. These cells may be equivalent of the "small bouquet catecholamine cells" of the rat retina (Nguyen-Legros et al., 1983), the noradrenaline-accumulating cells of the rat (Fukuda et al., 1982), or the second type of dopaminergic cell of the rhesus monkey (Mariani \& Hokoc, 1988). It appears that in cats, if these cells are the equivalent of some or all of the above amacrine cells, these amacrine cells do not retain their initial neurotransmitter signature into the adult.

A possibility that should be considered is that the Type 2 cells staining faintly with Toh antibodies are part of the group of amacrine cells that die early in development (Robinson, 1988). The wave of cell death in the INL, however, is reported to occur between E50 and P2 (Robinson, 1988). We are able to stain Type 2 cell bodies until P20 stages though. Thus, it seems more likely that they are an amacrine cell group that uses Toh only for a short period of time. A transient use of certain biochemical pathways and changes in neurotransmitter content or synthetic precursors in populations of neurons is not unprecedented in the mammalian retina. For example, in the rabbit and mouse retina, horizontal cells can be stained for a short time during development with $\left[{ }^{3} \mathrm{H}\right]-\mathrm{GABA}$ and anti-GAD antibodies, respectively, but not in the adult (Redburn \& Madtes, 1986; Schnitzer \& Rusoff, 1984).

An interesting corollary to a transient neurotransmitter content is the transient occurrence of dopamine D2 receptors on kitten ganglion cells. According to Ikeda and Robbins (Ikeda \& Robbins, 1988), all types of cat ganglion cells have D2 receptors that mediate both externally applied dopamine and noradrenaline action. We know from circuitry considerations of the Type 1 dopaminergic amacrine cell that dopamine is not released directly onto ganglion cells in the adult cat retina, so the hypothesis has been forwarded that dopamine innervation is initially present on ganglion cells, but that it is eliminated during postnatal development (Ikeda \& Robbins, 1988). Could the transient Type 2 Toh + amacrine cells described in this paper be responsible for this initial and transient dopaminergic innervation?

\section{Note added after acceptance of this paper}

We noted with interest the paper by Mitrofanis, Maslim, and Stone on the "Ontogeny of catecholaminergic and cholinergic cell distributions in the cat's retina" (Journal of Comparative Neurology 289, 228-246). The findings of that paper are very similar to ours concerning numbers of cells, but their findings show some differences from ours concerning topographical distributions of the developing population of Type 1 Toh + cells. This may mean that the dynamics of the topographic development of the population may vary between individual kittens and that there is no simple developmental rule underlying their final distribution.

\section{Acknowledgments}

This work was supported by Grant NNSF 3861004 from China, to H.-H. Wang, a grant from the Generalitat Valenciana, Spain, to N. Cuenca, and Grant EY03323 to H. Kolb.

\section{References}

Crooks, J. \& Morrison, J.D. (1989). Synapses of the inner plexiform layer of the area centralis of kitten retina during postnatal development: a quantitative study. Journal of Anatomy 163, 33-47.

DACEY, D.M. (1988). Dopamine-accumulating retinal neurons revealed by in vitro fluorescence display a unique morphology. Science $\mathbf{2 4 0}$, $1196-1198$.

DACEY, D.M. (1989). Axon-bearing amacrine cells of the macaque monkey retina. Journal of Comparative Neurology 284, 275-293.

FAMiglietti, E.V. \& KolB, H. (1975). A bistratified amacrine cell and synaptic circuitry in the inner plexiform layer of the retina. Brain Research 84, 293-300.

Fukuda, M., Ishimoto, I., Kuwayama, Y., Shimizu, Y., Shiosaka, Y., TAKAGI, H. \& ToHYAMA, M. (1982). Monoamine-accumulating neuron system in the rat retina with special reference to noradrenaline accumulating neurons. Experimental Eye Research 34, 487-491.

Hokoc, J.N. \& Mariani, A.P. (1988). Synapses from bipolar cells onto dopaminergic amacrine cells in cat and rabbit retina. Brain Research 461, 17-26.

IKEDA, H. \& RoBbins, J. (1988). Dopamine-less D2 receptors on feline retinal ganglion cells. In Dopaminergic Mechanisms in Vision, Ed. Bodis-Wollner, 1. \& Piccolino, M. pp. 179-191, New York: Alan $R$. Liss, Inc.

Johns, P.R., Rusoff, A.C. \& Dubin, M.W. (1979). Postnatal neurogenesis in the kitten retina. Journal of Comparative Neurology 187, 545-556.

Kolb, H., Cuenca, N., Wang, H. \& DeKorver, L. (1990) The synaptic organization of the dopaminergic amacrine cell in the cat retina. Journal of Neurocytology (in press).

KolB, H. \& FamiglietTi, E.V. (1974). Rod and cone pathways in the inner plexiform layer of the cat retina. Science 186, 47-49.

Kolb, H. \& Nelson, R. (1983). Rod pathways in the retina of the cat. Vision Research 23, 301-312.

Kolb, H., Nelson, R. \& Mariani, A. (1981). Amacrine cells, bipolar cells, and ganglion cells of the cat retina. Vision Research 21, 1081-1114.

KoLB, H. \& WEST, R.W. (1977). Synaptic connections of the interplexiform cell in the retina of the cat. Journal of Neurocytology 6 , $155-170$.

Kong, Y.C., Fung, S.C. \& LAM, D.M.K. (1980). The postnatal development of glycinergic neurons in rabbit retina. Journal of Comparative Neurology 193, 1127-1135.

LAM, D.M.K., FUNG, S.C. \& KonG, Y.C. (1980). The postnatal development of GABAergic neurons in the rabbit retina. Journal of Comparative Neurology 193, 89-102.

LAM, D.M.K., FunG, S.C. \& KonG, Y.C. (1981). Postnatal development of dopaminergic neurons in the rabbit retina. Journal of Neuroscience 1, 1117-1132.

Mariani, A.P. \& Hoкoc, J.M. (1988). Two types of tyrosine hydroxylase-immunoreactive amacrine cells in the rhesus monkey. Journal of Comparative Neurology 276, 81-91.

Mariani, A.P., Kolb, H. \& Nelson, R. (1984). Dopamine-containing amacrine cells of rhesus monkey retina parallel rods in spatial distribution. Brain Research 322, 1-7.

McArdle, C.B., Dowling, J.E. \& Masland, R.H. (1977). Development of outer segments and synapses in the rabbit retina. Journal of Comparative Neurology 175, 253-274. 
Mitrofanis, J., VignY, A. \& Stone, J. (1988). Distribution of catecholaminergic cells in the retina of the rat, guinea pig, cat, and rabbit: independence from ganglion cell distribution. Journal of Compara tive Neurology 267, 1-14.

Morrison, J.D. (1982). Postnatal development of the area centralis in the kitten retina: an electron microscopic study. Journal of Anatomy 135, 255-271.

NGUYEN-LEgros, J. (1988). Morphology and distribution of catecholamine neurons in mammalian retina. Progress in Retinal Research 7, 113-147.

NguYen-Legros, J., Vigny, A. \& Gay, M. (1983). Postnatal development of TH-like immunoreactivity in the rat retina. Experimental Eye Research 37, 23-32.

Nishimura, Y. \& Rakic, P. (1985). Development of the rhesus monkey retina, I: Emergence of the inner plexiform layer and its synapses. Journal of Comparative Neurology 241, 420-434.

Oyster, C.W., Takahashi, E.S., CillufFo, M. \& Brecha, N. (1985). Morphology and distribution of tyrosine hydroxylase-like immunoreactive neurons in the cat retina. Proceedings of the National Academy of Sciences of the U.S.A. 82, 6335-6339.

Parkinson, D., SPIRA, A., Wyse, J.P. \& Patten, M. (1985). The ontogenesis of the dopaminergic cell in the pre- and post-natal guineapig retina. International Journal of Developmental Neuroscience 3 , $157-167$

PouRCHo, R.G. (1982). Dopaminergic amacrine cells in the cat retina. Brain Research 252, 101-109.

Redburn, D.A. \& MAdTes, J.P. (1986). Postnatal development of $\left[{ }^{3} \mathrm{H}\right]-\mathrm{GABA}$-accumulating cells in rabbit retina. Journal of Comparative Neurology 243, 41-57.

RoBinson, S.R. (1988). Cell death in the inner and outer nuclear layers of the developing cat retina. Journal of Comparative Neurology 267, 507-515.
Savy, C., Yelnik, J., Martin-Martinelli, E., Karpouzas, I. \& NGUYEN-LEGROS, J. (1989). Distribution and spatial geometry of dopamine interplexiform cells in the rat retina; $\mathrm{I}$ : Developing retina. Journal of Comparative Neurology 289, 99-110.

Schnitzer, J. \& RuSoff, A.C. (1984). Horizontal cells of the mouse retina contain glutamic acid decarboxylase-like immunoreactivity during early developmental stages. Journal of Neuroscience 4, 2948-2955.

Steinberg, R.M., Reid, M. \& Lacy, P.L. (1973). The distribution of rods and cones in the retina of the cat (Felis domesticus). Journal of Comparative Neurology 148, 229-248.

Sterling, P. (1983). Microcircuitry of the cat retina. Annual Reviews of Neuroscience 6, 149-185.

Sterling, P., Freed, M.A. \& Smith, R.G. (1988). Architecture of rod and cone circuits to the on-beta ganglion cell. Journal of Neuroscience 8, 623-642.

Stone, J., Maslm, J. \& Rapaport, D. (1984). The development of the topographical organisation of the cat's retina. In Development of Visual Pathways in Mammals, eds. Stone, J., Dreher, B. \& RAPAPORT, D.H., pp. 3-21, New York: Alan R. Liss, Inc.

Törk, 1. \& StONE, J. (1979). Morphology of catecholamine-containing amacrine cells in the cat's retina, as seen in retinal wholemounts Brain Research 169, 261-273.

VANEY, D.I. (1985). The morphology and topographic distribution of AII amacrine cells in the cat retina. Proceedings of the Royal Society $B$ (London) 224, 475-488.

VoIGT, T. \& WÄSSLE, H. (1987). Dopaminergic innervation of AII amacrine cells in mammalian retina. Journal of Neuroscience 7 , 4115-4128.

Wulle, I. \& Schnitzer, J. (1989). Distribution and morphology of tyrosine hydroxylase-immunoreactive neurons in the developing mouse retina. Developmental Brain Research 48, 59-72. 